\author{
В.М. Биков ${ }^{1}$, М.М. Колчігін ${ }^{1}$, Я.М. Кожушко ${ }^{2}$, О.М. Гричанюк ${ }^{2}$ \\ ${ }^{1}$ Харківський наџіональний університет ім. В.Н. Каразіна, Харків \\ ${ }^{2}$ Харківський національний університет Повітряних Сил ім. І. Кожедуба, Харків
}

\title{
ОЦІНКА ТОЧНОСТІ ВИМІРЮВАННЯ КООРДИНАТ ОБ'ЄКТІВ МАТРИЧНИМИ КОРРЕЛЯЦІЙНО-ЕКСТРЕМАЛЬНИМИ СИСТЕМАМИ НАВІГАЦІЇ
}

У статті розглядаються питання, пов'язані з проведенням кількісної оцінки потенційної точності вимірювання координат точкових (що займають малу частину кадру), протяжних і площадних (що займають значну частину кадру) дотичних та недотичних об'єктів за допомогою матричних кореляційноекстремальних систем навігації. Аналізовані об'єкти можуть бути використані як навігаџійні орієнтири, координати яких при поетапному візуванні можуть бути визначені матричною кореляційноекстремальною системою навігації з високою точністю.

Ключові слова: еталонне зображення, зсув, кадр, кореляційно-екстремальна система, навігація, оцінка, поточне зображення.

\section{Вступ}

Кореляційно-екстремальні системи знаходять широке застосування в високоточних системах навігації літальних апаратів (ЛА) різних класів по наземних об'єктах, в системах наведення і самонаведення керованих засобів ураження на різні об'єкти, для високоточної доставки ЛА в різні райони земної поверхні [1-4].

Міліметровий діапазон вигідно відрізняється від більш низькочастотних діапазонів (сантиметрового, дециметрового) можливістю формувати зображення об'єктів в малому інформативному обсязі, тобто при малих витратах інформаційної техніки (наявності малогабаритних інформативних датчиків) на одиницю формованого датчиком поля інформативного параметра (інформативної ознаки).

Від більш короткохвильових діапазонів (інфрачервоного і видимого діапазонів) ММД відрізняється більш високим рівнем всепогодності, тобто можливістю надійно функціонувати в несприятливих погодних умовах. Функціонування радіоліній субміліметрового діапазону (з довжиною хвиль) обмежена нерівномірністю ослаблення радіохвиль цього діапазону при поширенні в прозорій атмосфері [5-7].

Постановка проблеми. Кількісна оцінка потенційної точності визначення місцезнаходження КЕСН відповідно до положень робіт [8-9] може здійснюватися наступним чином:

1. Будується модель поточного зображення (П3), який формується матричною КЕСН в процесі огляду земної поверхні, здійснюваного по ходу руху ЛА 3 певною швидкістю і під певним кутом до візуємої поверхні. Пред'являються вимоги до інформаційних датчиків матричної КЕСН.
2. Визначаються розміри візуємого багатопроменевою антеною “кадру” (форми растра), параметри розрізняємих елементів на земній поверхні, що обумовлені розмірами проекцій перерізів діаграм спрямованості антени (ДСА) парціальних каналів (датчиків), закони руху розрізняємих елементів i закони зміни вихідних сигналів матричного датчика.

3. Задається представлення візуємого об'єкту орієнтира навігації і навколишнього фону. Робляться припущення про наявність чи відсутність апріорної інформації про параметри, що оцінюються, та заважаючих (обмежуючих) параметрах.

На основі цих припущень вибирається критерій оптимальності. Знаходиться система рівнянь, що описує алгоритм оптимальної обробки сигналів матричної КЕСН. Рішення системи рівнянь дозволяє знайти глобальний екстремум критерію оптимальності і дисперсії оцінок аналізованих параметрів. Дисперсії або середньоквадратичні помилки (СКП) [10-11] оцінюваних параметрів $є$ шуканою мірою точності.

Підхід може бути застосований для оцінки точності визначення координат об'єктів різної форми: точкових (що займають малу частину кадру), протяжних і площадних (що займають значну частину кадру), а також радіолокаційних і радіометричних (PM) КЕСН, що працюють в різних ділянках радіота видимого діапазонів електромагнітних хвиль. Відмінності в оцінці для різних систем складаються в початкових висотах і кутах візування кадру, параметрах сигналів, що випромінюються та / або перевідбиваються об'єктом або фоном.

Таким чином, мета статті полягає в розробці методики оцінки точності вимірювання координат об'єктів простої і складної форми (конфігурації) ма- 
тричними радіометричними кореляційно-екстремальними системами навігації міліметрового діапазону хвиль.

\section{Виклад основного матеріалу}

В якості моделі аналізованого зображення прийнята зонна модель (рис. 1), в якій об'єкт 3 одним яскравісним наповненням (радіояскравісною температурою $S_{m}$ ) розташований на однорідному фоні $з$ іншим яскравісним наповненням (наприклад, на траві, у лісі і т.д.).

Огляд земної поверхні здійснюється паралельно за допомогою багатопроменевої антени матричної радіометричної (МРМ) КЕСН, що рухається в площині $x y$ під деяким кутом до осі $z$ системи координат $x, y, z$, що зв'язана з поверхнею землі, у точці $\left(x_{0}, y_{0}, z_{0}\right)$.

Багатопроменева антена формує матрицю $3 N_{1}$ строк та $N_{2}$ стовбців; нахил площини, в якій лежать вісі строчних ДСА, завданий кутом $\beta_{i}\left(i \in \overline{1, N_{1}}\right)$ відносно вектору швидкості ЛА, а положення вісі ДСА у строчці характеризується кутом $\alpha_{i j}\left(i \in \overline{1, N_{1}}, j \in \overline{1, N_{2}}\right)$. Ширина кожної ДСА за рівнем $3 d B$ дорівнює $\theta_{x}$ в кутомісній та $\theta_{y}-$ в азимутальній площині. Кожна парціальна ДНА апроксимується гаусовою поверхнею, що перерахована до координат.

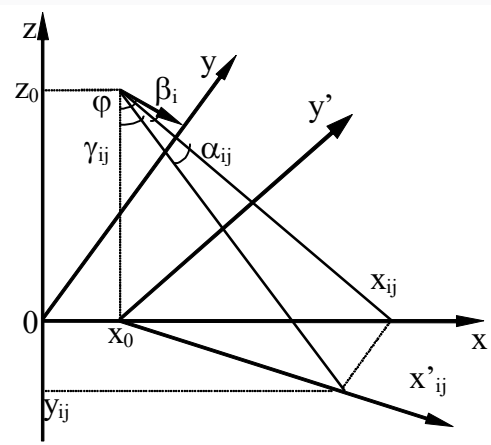

Рис. 1. Модель формування зображення Джерело: розроблено авторами.

Об'єкт складної форми представляє собою набip $N$ прямокутників в площині 3 вершинами $\left(a_{i}, b_{i}, c_{i}, d_{i}\right)$, розмірами $\Delta l_{x i}, \Delta l_{y i}$ вдовж відповідних осей та радіояскравісними температурами $T_{i}$.

Позначимо через $\varepsilon_{y}=c_{1}$ координати точки прицілювання, $\Delta T_{i}-T_{\mathrm{Tм}}-$ радіояскравісний контраст $i$-го об'єкту відносно фону.

Будемо вважати, що датчики РМ зображення $є$ безінерційні, їх власні шуми взаємонезалежні і яв- ляють собою нормально розподілені випадкові величини з нульовим середнім значенням та дисперсі$\epsilon ю \sigma^{2}$, при цьому взаємодія шуму з корисним сигналом має адитивний характер.

На рис. 2 приведена геометрія візування об'єкту прямокутної форми, в окремому випадку квадрата (аналог даху будинку з бітумним покриттям) 3 можливістю його розширення по одній зі сторін (по осі).

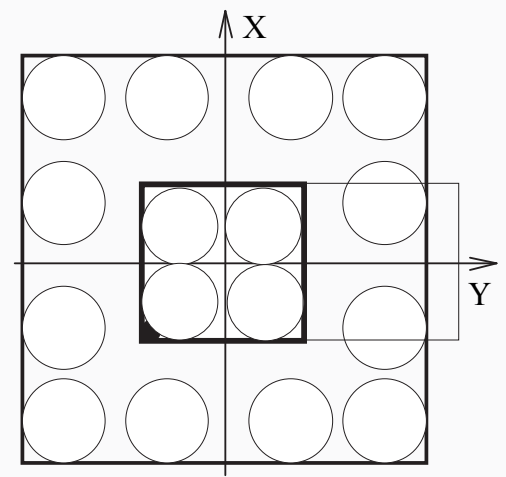

Рис. 2. Об’єкт прямокутної форми Джерело: розроблено авторами.

Великий квадрат позначає кадр, що візується на земній поверхні. Розміри кадру обумовлюються величиною СКО основної інерційної системи навігації ЛА, яка усувається за допомогою кореляційноекстремальними системами навігації [2]. 3 висоти польоту ЛА $1 \kappa м$ розміри кадру складають 180 м $\times 180$ м. Кружками в кадрі позначено приблизне розташування проекцій парціальних ДНА багатопроменевої антени. На рис. 3, б представлені два дотичних та два недотичних об'єкти прямокутної форми з розмірами $70 \mu \times 70 \mu$ кожен, з можливістю переміщення одного з об'єктів (наприклад, верхнього) уздовж осі $y$ (аналог двох дахів або одного даху складної форми).

На рис.4 показано візування об'єкта складної форми; в кадр потрапляє перетин трьох бетонних доріжок: двох горизонтальних доріжок шириною $40 \mu$ та $20 \mu$ з'єднуючої їх вертикальної доріжки завдовжки $60 \mathrm{~s}$ і шириною $40 \mathrm{~m}$. Повна довжина горизонтальних доріжок набагато більше розмірів кадру. Фоном для об'єктів є трав'яний покрів на земній поверхні. Оцінюваними параметрами прийнятого та аналізуємого матричними радіометричними кореляційно-екстремальними системами навігації сигналу є координати $\left(\varepsilon_{x}, \varepsilon_{y}\right) .3$ відсутністю апріорної інформації про параметри, що оцінюються, як критерій оптимальності обраний критерій максимуму правдоподібності [12]. 


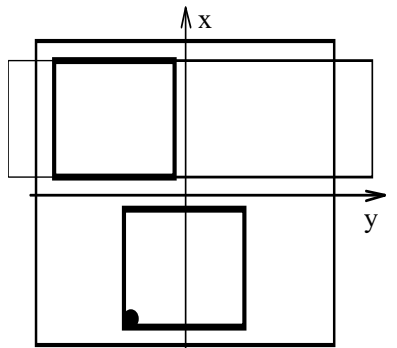

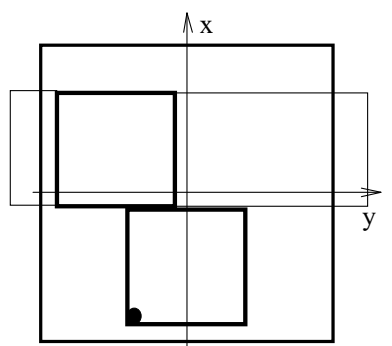

6
Рис. 3. Два дотичних та два недотичних об'єкти Джерело: розроблено авторами.

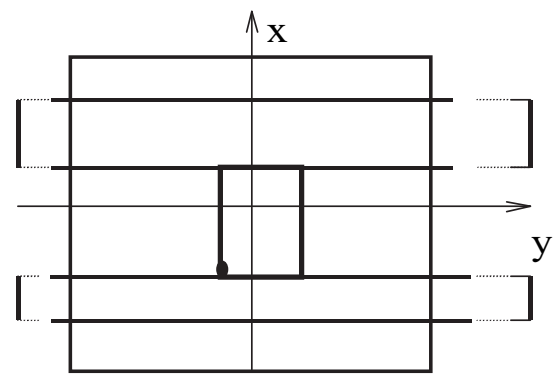

Рис. 4. Об'єкт складної конфігурації Джерело: розроблено авторами.

Користуючись аналогічними, вказаними у роботі [1] методами, для СКВ оцінок параметрів $\left(\varepsilon_{x}, \varepsilon_{y}\right)$ можна отримати співвідношення:

$$
\begin{aligned}
& \sigma_{x}=\left\|f_{y}\right\| / F\left(\varepsilon_{x}, \varepsilon_{y}\right), \\
& \sigma_{y}=\left\|f_{x}\right\| / F\left(\varepsilon_{x}, \varepsilon_{y}\right)
\end{aligned}
$$

де

$$
\mathbf{f}=\left[f_{i j}\right], i \in \overline{1, N_{1}}, j \in \overline{1, N_{2}} \text {; }
$$

$f_{i j}\left(\varepsilon_{x}, \varepsilon_{y}\right)=\sum_{k=1}^{N} \Delta T_{k}\left[\Phi\left(\frac{a_{k}+\Delta l_{x k}-x_{i j}^{0}}{\delta_{x}}\right)-\Phi\left(\frac{a_{k}-x_{i j}^{0}}{\delta_{x}}\right)\right] \times$ $\times\left[\Phi\left(\frac{c_{k}+\Delta l_{k}-y_{i j}^{0}}{\delta_{y}}\right)-\Phi\left(\frac{c_{k}-y_{i j}^{0}}{\delta_{y}}\right)\right]$; $\|\mathbf{f}\|=\left(\sum_{i=1}^{N_{1}} \sum_{j=1}^{N_{2}} f_{i j}\right)$ - норма матриці;

$\delta_{x}, \delta_{y}-$ описані в [1] параметри апроксимуючої ДСА гаусоіди,

що дозволяють оцінити потенційну точність визначення місцезнаходження літального апарату, що забезпечується матричної КЕСН, зокрема матричної РМ КЕСН. На рис. 5 а,б приведені залежності СКВ визначення координат об'єкту прямокутної форми (відповідно, $y$ та $x$ складові) від величини $\Delta l_{y}$ при співвідношенні сигнал-шум в П3 $q=\Delta T_{1} / \sigma=3$ при $\left(\Delta T_{1}=T_{T M}-T_{1}\right)$. При цьому значення радіояскравісної температури фону $T_{\mathrm{Tм}}=270 \mathrm{~K}, \quad$ об'єкту $T_{1}=267 \mathrm{~K}$, СКВ шуму $\sigma=1 \mathrm{~K}$.
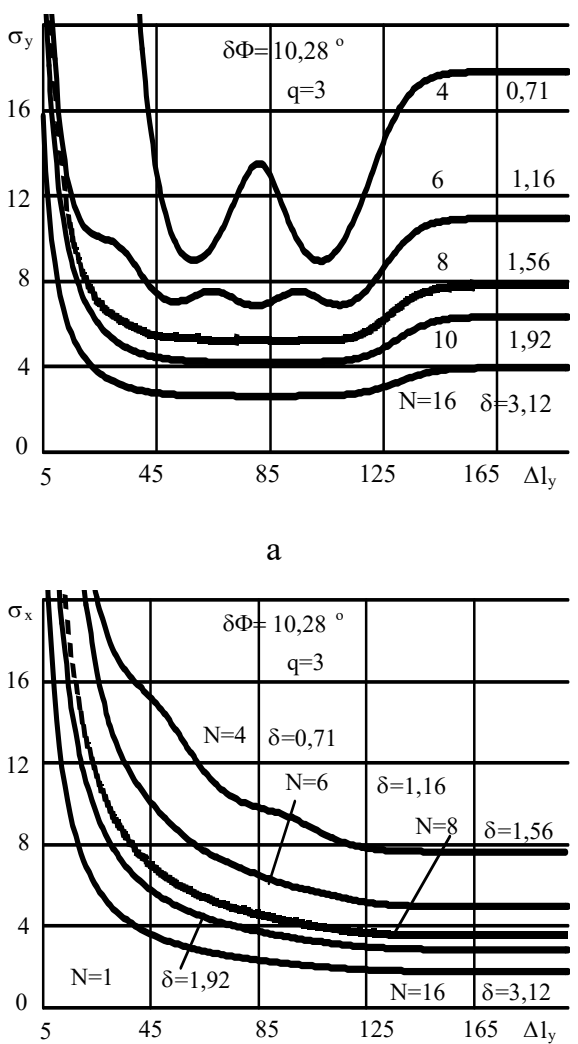

6

Рис. 5. СКВ визначення координат об'єкту прямокутної форми

Джерело: розроблено авторами.

Аналізується випадок вертикального візування кадру на земній поверхні. Повний кут обзору кадру 3 розмірами з висоти становить $\delta \Phi=10,28^{\circ}$, необхідною умовою $є$ розміщення променів всіх парціальних ДСА матричної антени у вказаному куті (“кадру").

Цифрами на рисунках позначено число променів ДСА в квадратній матриці, а також відповідні ним значення коефіцієнтів перетину сусідніх ДСА $\delta$. Ширина променя парціальних ДСА $\theta \approx 2^{\circ}$ при діаметрі параболічної чи лінзової антени $30 \mathrm{~cm}$ (робоча довжина хвилі $\lambda \approx 8$ мм ). На графіках можна виділити три області. Перша область відповідає низькій точності визначення місцезнаходження внаслідок того, що об'єкт при фіксованих розмірах по осі $x(70 \mu)$ має незначні кутові розміри по осі $y$ відносно $\theta_{y}$. Потім, у міру зростання об'єкта по осі 
$y, \sigma_{x}$ монотонно зменшується, що обумовлено накопиченням сигналу, що приймається по строковим променям. Величина $\sigma_{y}$ вагається щодо деякого середнього значення, при цьому амплітуда коливань знижується зі збільшенням коефіцієнта перетину $\delta$. Інформативність зображення в напрямку осі $y$ при цьому падає, точність $\sigma_{y}$ зменшується до значення, яке вона приймає при нескінченному подовженні сторони прямокутника.

Результати, наведені на рис. 5, показують, що застосування матричних РМ КЕСН з кількістю променів $6 \times 6$ і більш дозволяє забезпечити точність визначення місцезнаходження координат площадного об'єкту до одиниць метрів. Збільшення розмірності матриці (більше $8 \times 8$ ), при незмінному $\delta \Phi$ недоцільно (невиправдано), по-перше, через зниження відношення сигнал-шум в зображенні внаслідок зростання міжканальних перешкод i, по-друге, в багатопроменевих антенах оптичного типу величина $\delta$ обмежена значенням $\delta \approx 2$ через мінімальне кутове розрізнення, що визначається за критерієм Релея [9].

Існує кілька причин, які можуть привести до істотного зменшення відношення сигнал-шум. До них, в першу чергу, відноситься ослаблення радіохвиль ММД в дощі великої інтенсивності (загасання радіохвиль 8 мм діапазону у дощі $з$ інтенсивністю $16^{\mathrm{MM}} /$ год дорівнює $\left.(4-5) d B / \kappa M\right)$. Помірні дощі інтенсивністю порядку 4 мM/ год, а також мокрий сніг 3 таким же змістом води здатні згладити (зменшити) контраст пари об'єкт-фон. Оскільки складові точності зворотно пропорційні відношенню сигналшум, необхідно забезпечити запас за величиною $q$ як за рахунок роботи по високо контрастним об'єктам (парам, групам об'єктів), так і завдяки застосуванню радіометричних датчиків матричних кореляційно-екстремальних систем навігації, що володіють високою температурною чутливістю. Збільшення кута візування по одній з координат (наприклад, за координатою $x$ ) до $45^{\circ}$ при незмінних розмірах кадру $(180 \mu \times 180$ м $)$ призводить до зменшення кута візування кадру до $5,16^{\circ}$, при цьому точність погіршується на $(8-10) \%$, коефіцієнт перетину променів парціальних ДСА зростає. Так, для матриці $8 \times 8$ коефіцієнт перетину дорівнює $5,16^{\circ}$, для матриці $16 \times 16-3,12^{\circ}$. У зв'язку з цим доцільно здійснювати візування кадру на земній поверхні під кутами $0^{\circ} \ldots 30^{\circ}$ від вертикалі.
На рис. 6-7 представлені залежності СКВ $\sigma_{y, x}$ від величини зсуву переміщуваного прямокутного об'єкту щодо фіксованого (при цьому об'єкти не перетинаються). Розрахунки проведені для випадку вертикального візування для матриці $8 \times 8$.

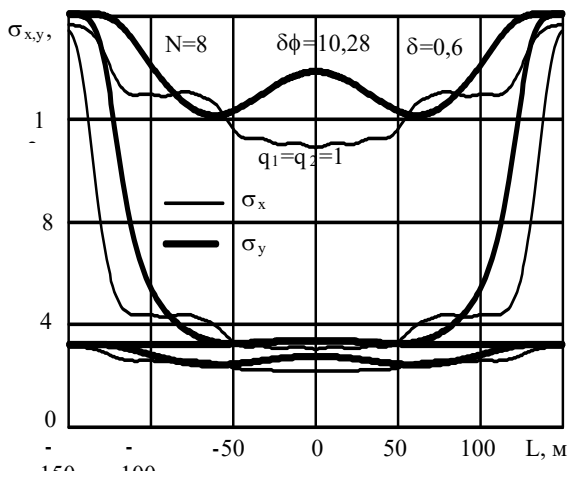

Рис. 6. Залежність СКО від величини зсуву $L$ об'єкти не дотичні

Джерело: розроблено авторами.

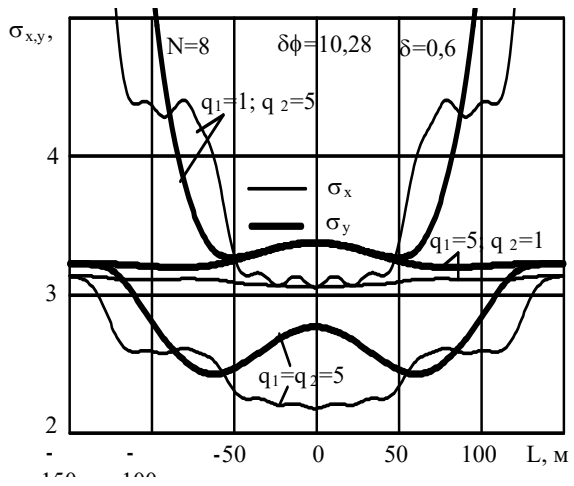

Рис. 7. Залежність СКО від величини зсуву $L$ Джерело: розроблено авторами.

На рис. 8 показане порівняння оцінок точності для двох матриць $8 \times 8$ и $16 \times 16$. Рис. 7 доповнює рис. 6 шляхом зміни масштабу в області малих значень помилки.

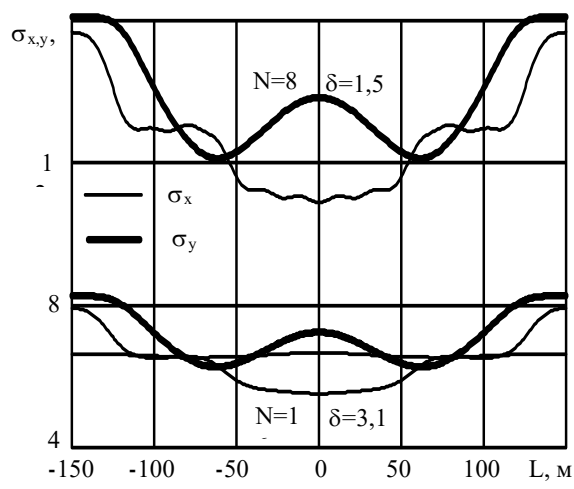

Рис.8. Залежність СКО від величини зсуву $L$ Джерело: розроблено авторами. 
Рис. 9 ілюструє результати порівняння величин СКВ для дотичних $(\Delta x=70 \mu)$ та недотичних обєктів $(\Delta x=90 \mu)$.

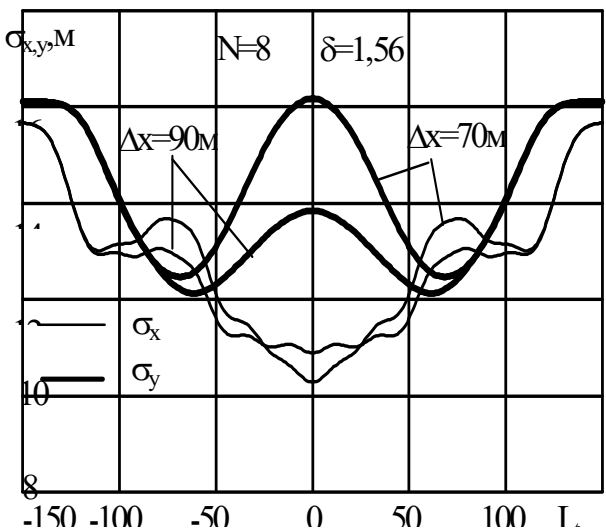

Рис. 9. Залежність СКО від величини зсуву $L$ Джерело: розроблено авторами.

Результати, що наведені на зазначених рисунках, отримані для випадку, коли точка прицілювання КЕСН знаходиться в лівому нижньому кутку основного об'єкту. На рис. 10, а,б наведені залежності СКВ визначення координат складного об'єкту (рис. 4) при переміщенні візуємого кадру по вісі $x$ (рис. 10, а) та вісі $y$ (рис. 10, б).
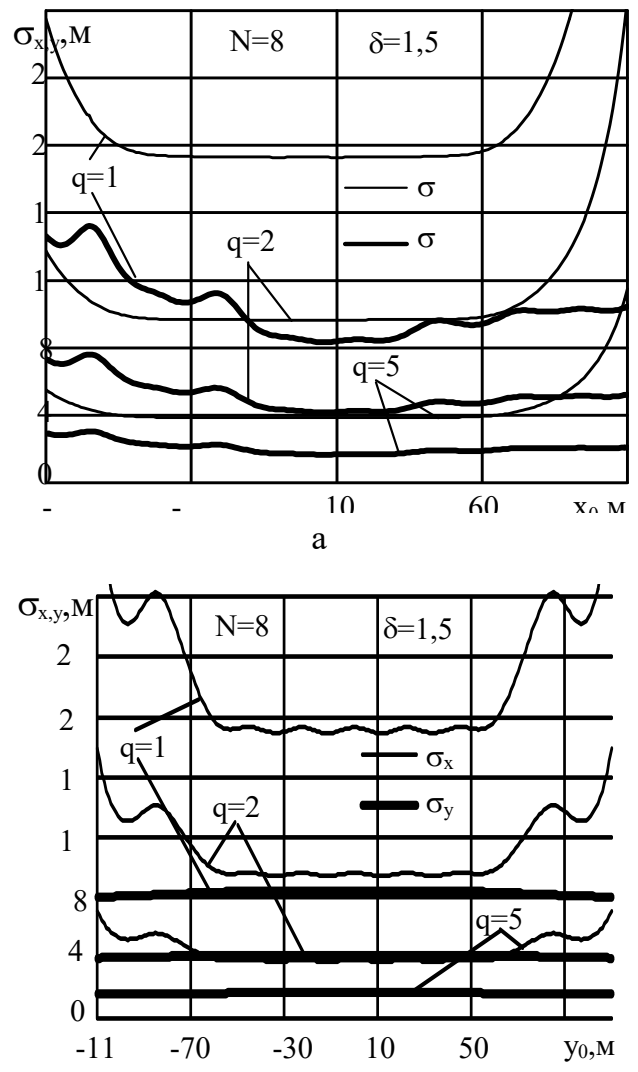

б

Рис.10. Залежність СКВ по вісях $x$ та $y$ Джерело: розроблено авторами.
Точка прицілювання кореляційно-екстремальної системи навігації знаходиться на перетині нижньої горизонтальної і вертикальної доріжок. Слід зазначити, що істотне погіршення точності визначення місцезнаходження даного об'єкту спостерігається в разі виходу з кадру вертикальної з'єднуючої доріжки $з$ розташованої на ній точкою прицілювання. При цьому об'єкт сприймається матричною кореляційно-екстремальною системою навігації у вигляді смуги нескінченної довжини з різними ознаками тільки по одній координаті.

\section{Висновки}

Аналіз проведених розрахунків, що наведені на графіках, дозволяє зробити наступні висновки:

Спостерігається сувора симетрія залежності величини помилки до появи в кадрі верхнього об'єкту та після його виходу з кадру.

При збігу положення об'єктів по вісі $x$ спостерігається мінімум помилки $\sigma_{y}$ у зв'язку з накопиченням сигналу по великій кількості парціальних променів ДСА, і деяке збільшення помилки $\sigma_{x}$.

Найкраща точність спостерігається при великому відношенні сигнал-шум двох об'єктів. Зменшення даного відношення до одиниці у допоміжного об'єкта незначно погіршує точність прив'язки до основного об'єкту.

При малому відношенні сигнал-шум у основного об'єкту величина точності визначається точністю допоміжного об'єкта до того моменту, поки він не вийшов 3 кадру, а далі точністю (низькою) основного об'єкту.

Визначення координат недотичних об'єктів здійснюється 3 меншим середньоквадратичним відхиленням, ніж дотичних, так як в цьому випадку прив'язка кореляційно-екстремальної системи навігації відбувається по об'єктах, що оточені однорідним фоном.

Розроблена методика дозволяє проводити кількісні оцінки потенційної точності вимірювання координат точкових, протяжних та площадних об'єктів за допомогою матричних кореляційно-екстремальних систем навігації. Аналізовані об'єкти можуть бути використані як навігаційні орієнтири, координати яких при поетапному візуванні можуть бути визначені матричною кореляційно-екстремальною системою навігації з високою точністю. 


\section{Список літератури}

1. Сотніков О. М., Таршин В. А., Опенько П. В. Проблеми та напрямки розвитку кореляційно-екстремальних систем наведення керованих літальних апаратів. Сучасні інформаційні технологї у сфері безпеки та оборони. 2013. № 3(18). С. 93-96.

2. Баклицкий В. К. Корреляционно-экстремальные методы навигации и наведения. Тверь : ТО “Книжный клуб”, 2009. $360 \mathrm{c}$

3. Баклицкий В. К., Бочкарев А. М., Мусьяков М. П. Методы фильтрации сигналов в корреляционноэкстремальных системах навигации. Москва : Советское радио, 1986. 216 с.

4. Щербинин В. В. Построение инвариантных корреляционно-экстремальных систем навигации и наведения летательных аппаратов. Москва : Изд-во МГТУ им. Н.Э. Баумана, 2011. 230 с.

5. Быков В. Н., Сотников А. М., Кожушко Я. Н. Обобщенная модель процесса функционирования матричной радиометрической корреляционно-экстремальной системы навигации миллиметрового диапазона. Системи управління, навігачіï та зв'язку. 2009. Вип. 3(11). С. 13-17.

6. Ingvessonm K. S. Imaging front-end systems for millimeter waves and submillimeter waves. SPIE. Instrumentation for submillimeter spectroscopy. 1985. Vol. 598. P. 104-113.

7. Танцюра О. Б. Аналіз методів комплексування різноспектральних зображень з використанням універсального показника якості. Наука і техніка Повітряних Сил Збройних Сил Украӥни. 2016. № 4(25). С. 152-156.

8. Антюфеев В. И., Быков В. Н., Макаренко Б. И. Потенциальная точность местоопределения матричными системами землеобзора. Электромагнитные волны и электромагнитные системы. 2001. Т.6. № 2-3. С. 101-106.

9. Antyufeev V. I., Vilchinski A. S., Bykov V. N., Grichanyuk A. M., Shokin M. G. Estimating the Coordinate Measurement Accuracy of Objects by Maximum-Correlation Navigation System. Telecommunications and Radio Engineering. 2001. Vol. 55. No. 2. P. 52-58

10. Герасимов С. В. Модель оцінки похибки обробки інформації у навігаційних системах крилатих ракет в умовах невизначеності. Наука $і$ т техніка Повітряних Сил Збройних Сил України. 2019. № 2(35). С. $151-157$. https://doi.org/10.30748/nitps.2019.35.19.

11. Герасимов С. В., Гричанюк А. М., Журавльов О. О. Дослідження високоточних систем навігації літальних апаратів за наземними орієнтирами. Збірник наукових пращъ Харківського наџіонального університету Повітряних Сил. 2017. № 5(54). C. 48-53.

12. Karlov D. Comparison of the Efficiency of Some Images Superposition Algorithms Used in Aircraft Map-Matching Navigation Systems. International Conference on Mathematical Methods in Electromagnetic Theory : conference paper. IEEE, 2018. P. 282-285. https://doi.org/10.1109/MMET.2018.8460319.

\section{References}

1. Sotnikov, O.M., Tarshyn, V.A. and Openjko, P.V. (2013), "Problemy ta naprjamky rozvytku koreljacijnoekstremaljnykh system navedennja kerovanykh litaljnykh aparativ" [Problems and directions of development of correlationextreme guidance systems of controlled aircraft], Modern information technologies in the field of security and defense, No. 3(18), pp. 93-96.

2. Baklyckyj, V.K. (2009), "Korreljacyonno-ekstremaljnye metody navyghacyy y navedenyja" [Correlation-extreme methods of navigation and guidance], Knyzhnyj klub, Tverj, $360 \mathrm{p}$.

3. Baklyckyj, V.K., Bochkarev, A.M. and Musjjakov, M.P. (1986), "Metody fyljtracyy syghnalov v korreljacyonnoekstremaljnykh systemakh navyghacyy" [Methods for filtering signals in correlation-extreme navigation systems], Soviet radio, Moscow, 216 p.

4. Shherbynyn, V.V. (2011), "Postroenye ynvaryantnykh korreljacyonno-ekstremaljnykh system navyghacyy y navedenyja letateljnykh apparatov" [Construction of invariant correlation-extreme systems of navigation and guidance of aircraft], Bauman University, Moscow, $230 \mathrm{p}$.

5. Bykov, V.N., Sotnykov, A.M. and Kozhushko, Ja.N. (2009), “Obobshhennaja modelj processa funkcyonyrovanyja matrychnoj radyometrycheskoj korreljacyonno-ekstremaljnoj systemy navyghacyy myllymetrovogho dyapazona" [Generalized model of the process of functioning of the matrix radiometric correlation-extremal millimeter-wave navigation system], Control, Navigation and Communication Systems, No. 3(11), pp. 13-17.

6. Ingvessonm, K.S. (1985), Imaging front-end systems for millimeter waves and submillimeter waves, SPIE. Instrumentation for submillimeter spectroscopy, Vol. 598, pp. 104-113.

7. Tancjura, O.B. (2016), "Analiz metodiv kompleksuvannja riznospektraljnykh zobrazhenj z vykorystannjam universaljnogho pokaznyka jakosti” [Analysis of methods of complexing multispectral images using a universal quality indicator], Science and Technology of the Air Force of Ukraine, No. 4(25), pp. 152-156.

8. Antjufeev, V.Y., Bykov, V.N. and Makarenko, B.Y. (2001), "Potencyaljnaja tochnostj mestoopredelenyja matrychnymy systemamy zemleobzora" [Potential Positioning Accuracy of Matrix Surveillance Systems], Electromagnetic waves and Electromagnetic Systems, Vol. 6, No. 2-3, pp. 101-106.

9. Antyufeev, V.I., Vilchinski, A.S., Bykov, V.N., Grichanyuk, A.M. and Shokin, M.G. (2001), Estimating the Coordinate Measurement Accuracy of Objects by Maximum-Correlation Navigation System, Telecommunications and Radio Engineering, Vol. 55, No. 2, pp. 52-58. 
10. Gherasymov, S.V. (2019), "Modelj ocinky pokhybky obrobky informaciji u navighacijnykh systemakh krylatykh raket $\mathrm{v}$ umovakh nevyznachenosti" [Model for estimating information processing error in cruise missile navigation systems under uncertainty], Science and Technology of the Air Force of Ukraine, No. 2(35), pp. 151-157. https://doi.org/10.30748/nitps.2019.35.19.

11. Gherasymov, S.V., Ghrychanjuk, A.M. and Zhuravljov, O.O. (2017), "Doslidzhennja vysokotochnykh system navighaciji litaljnykh aparativ za nazemnymy orijentyramy" [Research of high-precision navigation systems of aircraft on landmarks], Scientific Works of Kharkiv National Air Force University, No. 5(54), pp. 48-53.

12. Karlov, D. (2018), Comparison of the Efficiency of Some Images Superposition Algorithms Used in Aircraft MapMatching Navigation Systems, International Conference on Mathematical Methods in Electromagnetic Theory: conference paper, IEEE, pp. 282-285. https://doi.org/10.1109/MMET.2018.8460319.

\section{Відомості про авторів:}

\section{Биков Віктор Миколайович}

доктор технічних наук старший науковий співробітник професор кафедри

Харківського національного університету

ім. В.Н. Каразіна,

Харків, Україна

https://orcid.org/0000-0002-5114-7868

\section{Колчігін Микола Миколайович}

доктор фізико-математичних наук професор

завідувач кафедри

Харківського національного університету

ім. В.Н. Каразіна,

Харків, Україна

https://orcid.org/0000-0002-5018-1060

\section{Кожушко Ярослав Миколайович}

кандидат технічних наук старший дослідник

старший науковий співробітник

Харківського національного університету

Повітряних Сил ім. І. Кожедуба

Харків, Україна

https://orcid.org/0000-0002-4229-6757

\section{Гричанюк Олександр Михайлович}

кандидат технічних наук

старший науковий співробітник

Харківського національного університету

Повітряних Сил ім. І. Кожедуба

Харків, Україна

https://orcid.org/0000-0002-9864-4968

\section{Information about the authors:}

\section{Viktor Bykov}

Doctor of Technical Sciences Senior Research

Professor of Department

of V.N. Karazin Kharkiv National

University,

Kharkiv, Ukraine

https://orcid.org/0000-0002-5114-7868

\section{Mykola Kolchigin}

Doctor of Physics and Mathematics Professor

Head of Department

of V.N. Karazin Kharkiv National

University,

Kharkiv, Ukraine

https://orcid.org/0000-0002-5018-1060

\section{Yaroslav Kozhushko}

Candidate of Technical Sciences Senior Research

Senior Research Associate

of Ivan Kozhedub Kharkiv National

Air Force University,

Kharkiv, Ukraine

https://orcid.org/0000-0002-4229-6757

\section{Oleksandr Hrichaniuk}

Candidate of Technical Sciences

Senior Research Associate

of Ivan Kozhedub Kharkiv National

Air Force University,

Kharkiv, Ukraine

https://orcid.org/0000-0002-9864-4968

\title{
ОЦЕНКА ТОЧНОСТИ ИЗМЕРЕНИЯ КООРДИНАТ ОБЪЕКТОВ МАТРИЧНИМИ КОРРЕЛЯЦИОННО-ЭКСТРЕМАЛЬНЫМИ СИСТЕМАМИ НАВИГАЦИИ
}

\author{
В.Н. Быков, Н.Н. Колчигин, Я.Н. Кожушко, А.М. Гричанюк
}

В статье рассматриваются вопросы, связанные с проведением количественной оиенки потенцильной точности измерения координат точечных (занимающие малую часть кадра), протяженных и площадных (занимающих значительную часть кадра) соприкасающихся и несоприкасающихся объектов с помощью матричных корреляционноэкстремальных систем навигачии. Рассматриваемые объекты могут быть использованы как навигационные ориентиры, координаты которых при поэтапном визировании могут быть определены матричной корреляиионноэкстремальной системой навигачии с высокой точностью.

Ключевые слова: эталонное изображение, сдвиг, кадр, корреляиионно-экстремальная система, навигаџия, оценка, текущее изображение. 


\section{ESTIMATION OF THE ACCURACY OF MEASURING THE COORDINATES OF OBJECTS BY MATRIX CORRELATION-EXTREME NAVIGATION SYSTEMS}

V. Bykov, N. Kolchigin, Ya. Kozhushko, O. Hrichaniuk

The article deals with issues related to the quantitative assessment of the potential accuracy of measuring the coordinates of point, long and area tangent and non-tangent objects using matrix CENS. The analyzed objects can be used as navigation landmarks, the coordinates of which in step-by-step sighting can be determined by a matrix CENS with high accuracy. Quantitative assessment of the potential accuracy of CENS is as follows: A model of the current image is built, in the process of inspecting the earth's surface, in the course of movement at a certain speed and at a certain angle to the surface. The frame sizes, parameters of the distinguished elements, laws of movement of the distinguished elements are defined. The representation of the intended object and the surrounding background is set. Assumptions are made about the presence or absence of a priori information about the parameters being evaluated and interfering parameters. Based on these assumptions, the criterion of optimality is selected. There is a system of equations that describes the algorithm for processing signals CENS. The solution of the system of equations allows to find the global extremum of the criterion of optimality and variance of estimates of the analyzed parameters. As the model of the analyzed image the zone model in which object with one luminous filling is located on a homogeneous background with other luminous filling is accepted. In the absence of a priori information about the parameters evaluated, the criterion of maximum plausibility is chosen as the criterion of optimality. It is shown that there is a strict symmetry of the error value before the appearance of the upper object in the frame and after its exit from the frame. The best accuracy is observed at a high signal-to-noise ratio of two objects. Decreasing this ratio to one in the auxiliary object slightly impairs the accuracy of binding to the main object. With a small signal-to-noise ratio in the main object, the accuracy is determined by the accuracy of the auxiliary object until it leaves the frame, and then the accuracy (low) of the main object. Determining the coordinates of nontangential objects is carried out with less SLE than tangential, as in this case, the binding of CENS is on objects surrounded by a homogeneous background. The developed technique allows to carry out quantitative estimations of potential accuracy of measurement of coordinates of point, extended and area objects by means of matrix CENS. The analyzed objects can be used as navigational landmarks, the coordinates of which in step-by-step sighting can be determined by the matrix CENS with high accuracy.

Keywords: reference image, shift, frame, correlation-extremal system, navigation, assessment, current image. 